\title{
Green sulphur bacteria as a component of the photosynthetic plankton community in small dimictic humic lakes with an anoxic hypolimnion
}

\author{
Jatta Karhunen $^{1, *}$, Lauri Arvola ${ }^{2}$, Sari Peura ${ }^{1,3}$, Marja Tiirola1 \\ ${ }^{1}$ Department of Biological and Environmental Science, University of Jyväskylä, PO Box 35, 40014 Jyväskylä, Finland \\ ${ }^{2}$ Lammi Biological Station, University of Helsinki, Pääjärventie 320, 16900 Lammi, Finland \\ ${ }^{3}$ Department of Microbiology and Immunology, University of Michigan, 1150 West Medical Center Drive, Ann Arbor, \\ Michigan 48109, USA
}

\begin{abstract}
High bacteriochlorophyll (BChl) concentrations in the anoxic water layers of some humic lakes have indicated that green sulphur bacteria (GSB) may be ecologically significant. The abundance and spatial distribution of GSB were therefore addressed in 13 small humic lakes using fragment analysis and sequencing of PCR-amplified 16S rRNA genes. GSB were detected from lakes where the photosynthetically active radiation was at least $1.1 \mu \mathrm{E} \mathrm{m}^{-2} \mathrm{~s}^{-1}$ at the oxicanoxic boundary layer. In these lakes, 13 to $42 \%$ of the 16S rRNA gene sequences of the anoxic water column were assigned to GSB. The spatial distribution of GSB was tightly correlated with the spectrophotometrically measured BChl concentration during the summer season. Maximum $\mathrm{BChl}$ concentrations were observed in the uppermost part of the anoxic water layer, covering most of the chlorophyll pigment in these lakes. The GSB of the humic lakes typically belonged to a phylogenetically homogenous group closely related to Chlorobium clathratiforme.
\end{abstract}

KEY WORDS: Chlorobium sp. · LH-PCR · Green sulphur bacteria · Humic lake · Boreal lake Resale or republication not permitted without written consent of the publisher

\section{INTRODUCTION}

The anaerobic microbiology of small humic lakes in the boreal zone is still largely unexplored. The few microscopic (e.g. Baker et al. 1985, Arvola et al. 1992) and molecular (Taipale et al. 2009, 2011, Peura et al. 2012) studies suggest that the microbial communities in anoxic layers of these lakes are dominated by bacteria, which are distinct from bacteria typical for epilimnetic communities, such as green sulphur bacteria (GSB) and candidate phylum OD1. GSB are strictly anaerobic and obligatory phototrophic; thus, they require the presence of reduced sulphur compounds and the availability of light for growth (Van Gemerden \& Mas 1995). Such habitat is provided by small humic lakes, where a combination of dark water colour and infrequent vernal mixing guarantees an optimal light and oxygen environment for these organisms.

GSB have a special light-capturing capability, which is based on very efficient light-harvesting pigments: bacteriochlorophylls (BChl) $c, d$ or e together with BChl $a$ and carotenoids (Olson 1998). Studies on the chlorophyll contents of photosynthetic microbial groups have shown that BChl types typical for GSB or multicellular filamentous green bacteria (MFGB) were abundant in most of the studied 24 North American kettle lakes (Vila et al. 1998), and in most of the 11 Spanish karstic dolines and coastal lagoons (Guerrero et al. 1987). As stated above, the environment in humic lakes also seemingly provides optimal growth conditions for GSB, but their prevalence in these lakes remains to be addressed. Further, analysis through chlorophyll content requires high-perfor- 
mance liquid chromatography (HPLC) analysis and should also consider the phenotypical variation of the pigment types and their contents in different GSB species. We opted to use molecular methods based on the marker genes found only in the organisms in question.

Chlorobium, which belongs to green subset of the GSB, was previously found to constitute an important carbon source for the lake food web in the small boreal humic lake Mekkojärvi, and it was the dominating species in the bacterial community (Taipale et al. 2009). The present study aimed to discover whether this is true for humic lakes in general. The survey covered 13 steeply stratified small boreal lakes that vary in terms of humic matter concentration, thermal and chemical stratification, as well as in the availability of photosynthetically active radiation (PAR) in their water columns. The abundance of GSB was studied using length heterogeneity analysis (LH$\mathrm{PCR}_{i}$ Suzuki et al. 1998) of polymerase chain reaction (PCR)-amplified 16S rRNA genes, and we sequenced several amplicons to study their phylogenetic affiliation. The study was supported by $\mathrm{BChl}$ analysis, which was performed during the open water season and under the ice.

\section{MATERIALS AND METHODS}

The study lakes were located in the Evo forest area in southern Finland (an area of $48 \mathrm{~km}^{2} 61^{\circ} 10^{\prime}$ to $61^{\circ} 13^{\prime} \mathrm{N}$ and $25^{\circ} 5^{\prime}$ to $25^{\circ} 12^{\prime} \mathrm{E}$ ). The lakes have an ice cover from approximately early November until the beginning of May. Spring mixing can be incomplete, but the autumnal overturn happens more reg- ularly in many of the lakes in the area (Salonen et al. 1984). The study lakes were stratified with regard to the availability of light, temperature, oxygen and nutrients (Table 1). Each lake was sampled 1 to 4 times in 2009. Seasonal changes in the abundance of GSB were followed in lakes Alinen Mustajärvi, Halsjärvi and Mekkojärvi, and GSB communities under ice were studied in Alinen Mustajärvi, Halsjärvi, Nimetön and Horkkajärvi.

Water samples were taken with a Limnos water sampler ( $30 \mathrm{~cm}$ height, 2.11 volume), at $0.5 \mathrm{~m}$ intervals from the oxic-anoxic boundary layer (oxygen saturation between 0 and $10 \%$ ) and at $1 \mathrm{~m}$ intervals from the other water layers. Methods for sample preparation, inorganic nutrient measurements and dissolved organic carbon (DOC) are explained in more detail in the supplement at www.int-res.com/articles/suppl/ a068p267_supp.pdf. The light intensities at different depths were calculated according to Wetzel (1983).

Bacterial DNA samples for the LH-PCR analyses were prepared using a lysate technique (detailed in the supplement). LH-PCR analysis was done according to Taipale et al. (2009), using $27 f$ (5'-AGA GTT TGA TCN TGG CTC AG-3'; Lane 1991) and 518r (5'ATT ACC GCG GCT GCT GG-3'; Muyzer et al. 1993) as primers in the PCR reaction for amplification of the 16S rRNA genes of bacteria, except that the polymerase brand used was DreamTaq by Fermentas. The peak size $512 \pm 1 \mathrm{bp}$ was used as a specific biomarker for Chlorobi spp., since previous results from Mekkojärvi, one of the lakes sampled for this study, revealed that this distinct fragment length corresponded to the genus Chlorobium according sequence analysis (Taipale et al. 2009). Therefore, we propose that the relative proportion of the $512 \pm 1$

Table 1. Maximum depth, depth of the oxic epilimnion, dissolved organic carbon (DOC) concentration, water colour and sampling times for the study lakes. Sampling dates - 1: 6 to 9 April 2009; 2: 14 to 15 May 2009; 3: 13 to 27 July 2009; 4: 11 August 2009

\begin{tabular}{|c|c|c|c|c|c|c|}
\hline Lake & $\begin{array}{c}\text { Max. } \\
\text { depth (m) }\end{array}$ & $\begin{array}{l}\text { Depth of oxic } \\
\text { epilimnion (m) }\end{array}$ & $\begin{array}{c}\text { DOC } \\
\left(\mathrm{mg} \mathrm{C}^{-1}\right)\end{array}$ & $\mathrm{pH}$ &  & $\begin{array}{l}\text { Sampling } \\
\text { date }\end{array}$ \\
\hline Alinen Mustajärvi & 7 & 2 & 12.1 & 5.16 & 133 & $1,2,3,4$ \\
\hline Halsjärvi & 6 & 2 & 6.8 & 6.23 & 130 & $1,2,3,4$ \\
\hline Mekkojärvi & 4 & 1 & 25.1 & 5.59 & 388 & $2,3,4$ \\
\hline Nimetön & 10 & 2 & 22.2 & 5.28 & 269 & 1,3 \\
\hline Tavilampi & 7 & 2 & 13.3 & 5.79 & 155 & 3 \\
\hline Särkijärvi & 3 & 1.5 & 14.1 & 6.33 & 206 & 3 \\
\hline Iso-Valkjärvi & 7 & 4 & 7.6 & 5.55 & 65 & 3 \\
\hline Huhmari & 9 & 1.5 & 10.7 & 6.24 & 139 & 3 \\
\hline Horkkajärvi & 10 & 1.5 & 22.4 & 5.62 & 325 & 1,3 \\
\hline Rieskalammi & 5 & 1 & 26.5 & 6.24 & 459 & 3 \\
\hline Keskinen Rajajärvi & 12 & 5.5 & 19.6 & 5.25 & 294 & 3 \\
\hline Ylinen Rajajärvi & 6 & 4.5 & 24.2 & 4.96 & 336 & 3 \\
\hline Vähä-Keltajärvi & 4 & 2 & 27.7 & 5.75 & 399 & 3 \\
\hline
\end{tabular}


peak size among the bacterial 16S rRNA PCR-amplified gene products can be used as an estimator of the relative abundance of GSB, and hereafter this relative proportion of GSB in the LH-PCR analysis is expressed as LH-PCR ${ }_{512}$.

To confirm the pertinence of the LH-PCR 512 biomarker and to study the diversity in the anaerobic microbial communities and Chlorobium spp. genotypes, clone libraries were constructed from lakes Alinen Mustajärvi, Halsjärvi, Mekkojärvi, Nimetön, Tavilammi, Särkijärvi, Iso-Valkjärvi and Huhmari from the depth of the maximum $\mathrm{BChl}$ concentration. DNA was extracted from freeze-dried water samples using $\mathrm{MO}$ BIO PowerSoil DNA isolation kit (MO BIO Laboratories). Amplification of the 16S rRNA gene was performed as described for LH-PCR, except that the reverse primer $907 \mathrm{R}$ (5'-CCG TCA ATT CMT TTR AGT TT-3'; Amann et al. 1992) was used to amplify longer sequences of $\sim 880 \mathrm{bp}$. Cloning and sequencing of the PCR products was performed as described by Taipale et al. (2009). From each sample, 24 clones were sequenced, adding up to a total of 192 sequences. The sequences have been deposited in the EMBL database under accession numbers HE793329-HE793375 and HF543675-HF543817 (details in the supplement).

For BChl determinations, 0.12 to $0.5 \mathrm{l}$ sample from each water layer was filtered through a GF/C filter (45 mm diameter, Whatman) and measured as described by Arvola et al. (1992). Because different BChls $(c, d$ and e) overlap greatly, but have different maximum absorptions (666, 655 and $654 \mathrm{~nm}$, respectively) (Frigaard et al. 1996), we measured the combined estimate of $\mathrm{BChl}$ at the $654 \mathrm{~nm}$ wavelength. Spectral overlapping of chlorophyll a ( $\mathrm{chl}$ a) and BChl peaks was corrected by a model based on the data from the water layers in which only one of the chlorophylls was present (Fig. S1 in the supplement at www.int-res.com/articles/suppl/a068p267_supp. pdf). The absorbance ratio of 665:654 nm (Arvola et al. 1992) indicated the boundary layer where the dominance of chl a shifted to BChl between oxic and anoxic water layers in these lakes.

Correlation between light intensity and BChl concentration, and correlation between LH-PCR ${ }_{512}$ results and $\mathrm{BChl}$ concentration were tested using Spearman's rank correlation (PASW Statistics 18, Release Version 18.0.0, SPSS).

\section{RESULTS AND DISCUSSION}

LH-PCR 512 and sequencing provided consistent evidence of the significant Chlorobium spp. popula- tion (representing at least 10\% the PCR-amplified 16S rRNA genes of the bacteria in any of the water layers) in 8 of the 13 study lakes. Supported by the strong correlation $(\rho=0.827$ and $p<0.001)$ between LH-PCR ${ }_{512}$ proportions and BChl concentrations, we were able to locate the maximum GSB abundance in the anoxic zone close to the oxic-anoxic boundary layer (Fig. 1). Based on the sequences of the bacterial 16S rRNA PCR-amplified genes, we estimated that the proportion of GSB varied between 14 and $38 \%$ of the bacterial community in this layer in the GSB-positive lakes.

The results showed that, although the light conditions in boreal humic lakes are poor, many of these lakes provide an ecological niche for GSB. The PAR intensity at the depth of the oxic-anoxic interface was higher in the lakes where GSB were abundant compared to in the lakes without GSB (1.1 to $24.2 \mu \mathrm{E}$ $\mathrm{m}^{-2} \mathrm{~s}^{-1}$ and $<0.1 \mu \mathrm{E} \mathrm{m} \mathrm{m}^{-2} \mathrm{~s}^{-1}$, respectively; corresponding to 0.08 to $1.7 \%$ and $<0.007 \%$ of the surface PAR, respectively). There was a clear relationship between PAR intensity at the oxic-anoxic interface and BChl concentration $(\rho=0.813$ and $p<0.001)$.

In GSB-positive lakes the estimate of BChl covered up to $92 \%$ (in Särkijärvi) of the total lake chlorophyll, and even the lowest proportion of BChl was $58 \%$ (in Huhmari) (Fig. S2 in the supplement at www.int-res. com/articles/suppl/a068p267_supp.pdf). The concentration of BChl more than doubled in all the study lakes between May and August. In Alinen Mustajärvi, the BChl was saturated in July, while in Halsjärvi and Mekkojärvi, the concentration of $\mathrm{BChl}$ increased over the course of the whole summer season (data not shown).

In 3 out of the 4 lakes that were studied during winter (Alinen Mustajärvi, Halsjärvi and Nimetön), GSB communities were found under ice, although the PAR conditions under the ice and snow in mid-winter did not support the phototrophic growth of GSB. The highest LH-PCR ${ }_{512}$ proportions were observed in the upper hypolimnion and $\mathrm{BChl}$ densities close to the bottom (Fig. S3 in the supplement at www.int-res. com/articles/suppl/a068p267_supp.pdf), indicating increasing abundance of other bacterial groups closer to the sediment, which decreased the relative abundance of GSB. The primary reason for the highest winter $\mathrm{BChl}$ concentrations near the bottom could be the aeration of the water column during autumnal mixing, leading to death of the majority of the GSB cells in the water column, except at the very bottom. Another possible explanation for the occurrence in deeper waters during winter could be cell sinking due to the loss of turbulence. Consistent with our 


\begin{tabular}{llllll|}
\hline$\bullet$ & BChl & $\cdots$ & $\cdots$ & $\cdots$ & LH$_{-P C R}$ \\
\hline
\end{tabular}

Alinen Mustajärvi

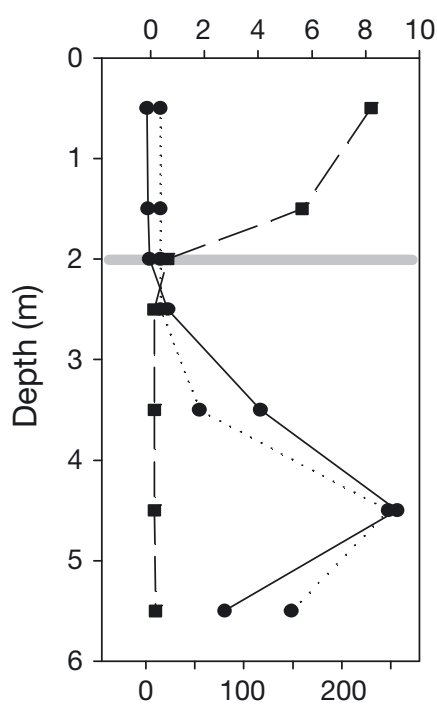

$\begin{array}{lllll}0 & 10 & 20 & 30 & 40\end{array}$
Mekkojärvi

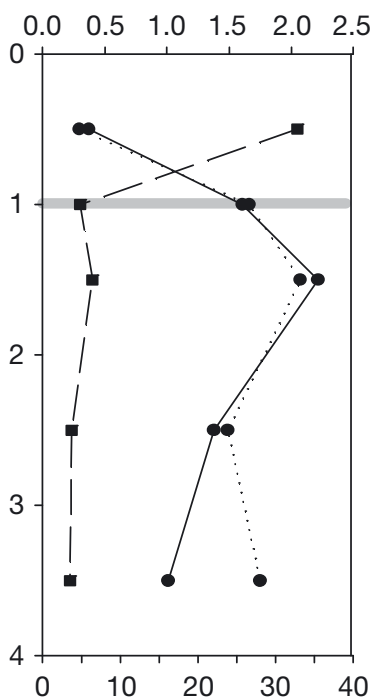

$\mathrm{O}_{2}\left(\mathrm{mg} \mathrm{l}^{-1}\right) \quad$ Iso Valkjärvi



\begin{tabular}{llllll}
\hline & 4 & 8 & 12 & 16
\end{tabular}

LH-PCR ${ }_{512}$ (\% of total intensity)

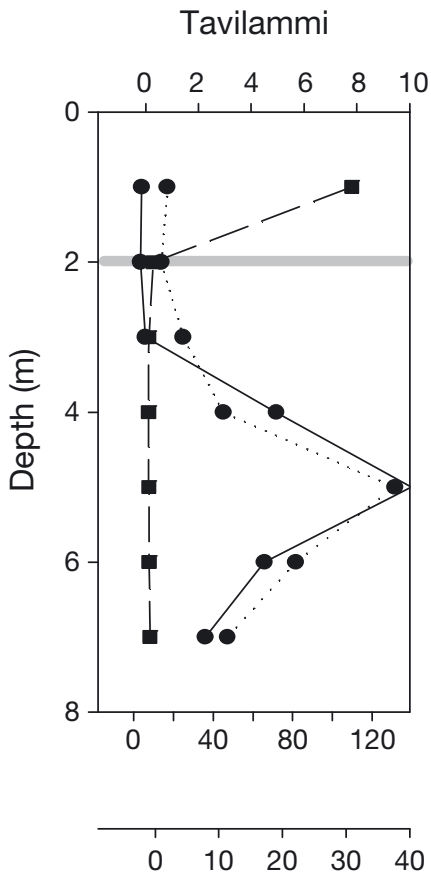

Nimetön

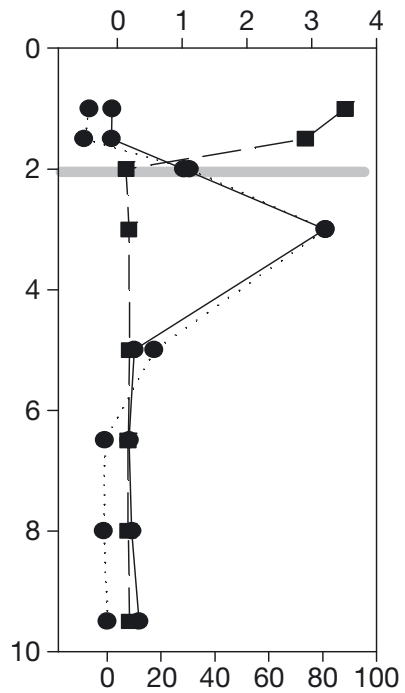

Huhmari
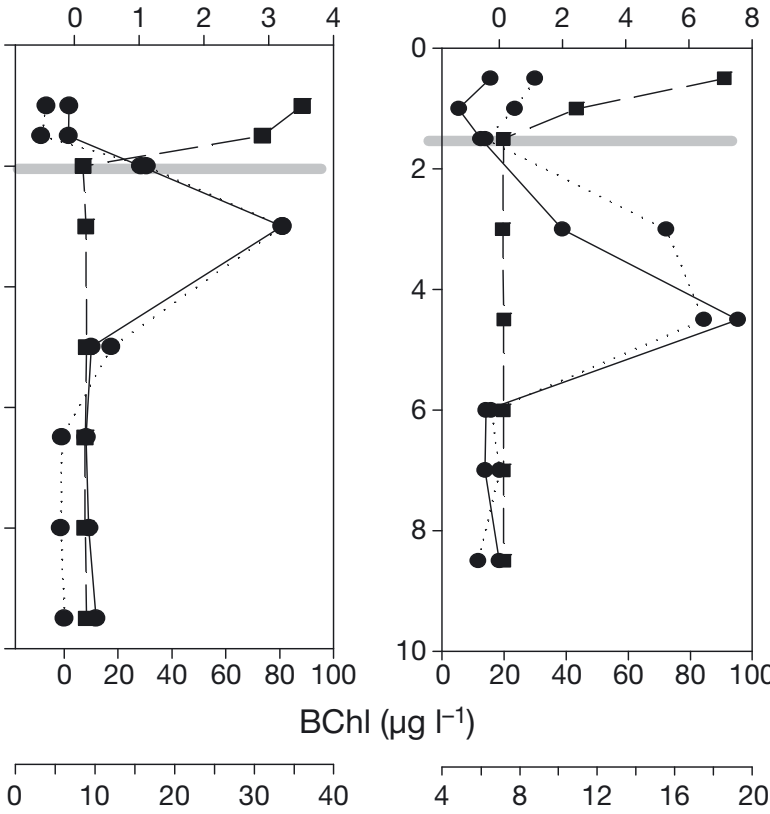

LH-PCR ${ }_{512}$ (\% of total intensity)
$\mathrm{O}_{2}\left(\mathrm{mg} \mathrm{l}^{-1}\right)$
Halsjärvi

results, Chlorobium sp. was also detected in Burton Lake (Antarctica), where light does not penetrate the water for 3 mo of the year (Burke \& Burton 1988). The dominance of Chlorobium sp. in Lake Burton was explained by their efficient maintenance metabolism in winter and by their great efficiency in utilizing low-intensity light (Burke \& Burton 1988).

Based on clone sequences recovered in libraries constructed from anoxic water, 13 bacterial phyla were identified, the main phyla being Proteobacteria, Chlorobi and Bacteroidetes (Fig. S4 in the supplement at www.int-res.com/articles/suppl/a068 p267_supp.pdf). From the total of 192 16S rRNA gene clones, $25 \%$ of clones were identified as Chlorobium sp., and no other known BChls containing bacterial groups were detected, except 5 clones of Chloroflexi that were found in Halsjärvi. The sequencing analysis validated the LH-PCR 512 biomarker $(512 \pm 1 \mathrm{bp})$ for the analysis of GSB abundance in the study lakes,

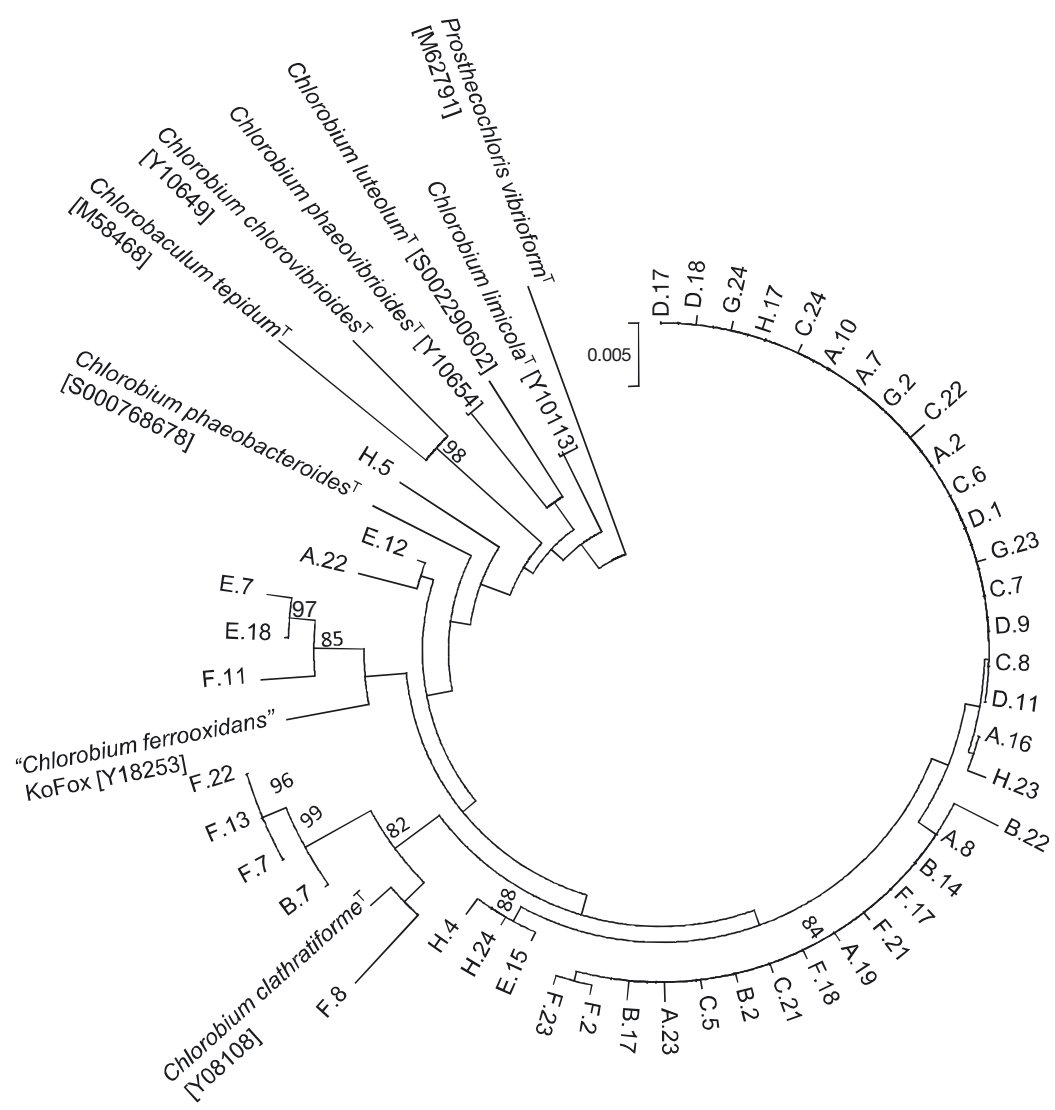

Fig. 2. Neighbour-joining tree of green sulphur bacteria in humic lakes and reference type strains of the genus Chlorobium based on partial 16S rRNA gene sequences. The tree was made of 798 aligned nucleotide positions. Bootstrap values $>70 \%$ and clustering of the study sequences to 4 coherent $\mathrm{OTU}_{0.97}$ (operational taxonomic unit) groups are shown. A: Alinen Mustajärvi; B: Halsjärvi; C: Mekkojärvi; D: Nimetön; E: Tavilammi; F: Särkijärvi; G: IsoValkjärvi; H: Huhmari as no other bacterial groups had the same fragment size in the V1 to V3 16S rRNA region, and LH-PCR and sequencing results were consistent among the samples. The clone libraries revealed close phylogenetic relationships among the GSB communities of different lakes (Fig. 2). The clustering analysis in $\mathrm{OTU}_{0.97}$ level (sequence length $\approx 880 \mathrm{bp}$ ) divided the clones into 4 clusters, of which 1 to 3 clusters were found in each lake. OTU1 comprised 36 reads; OTU2, 5 reads; and OTUs 3 and 4, 3 reads. OTU1 was the most homogenous of all OTUs, but it had the largest distance to any type strain. Still, OTU1 had the closest match to Chlorobium clathratiforme, which was also clustered with OTU2. OTU3 clustered with Chlorobium ferroxidans; and OTU4, with Chlorobium phaeobacteroides (Fig. 2).

Chlorobium clathratiforme is known to belong to the green subset of the GSB, and its pigment composition has been reported to be BChl $c$, $d$, or both (Gich et al. 2001). In Lago di Cadagno, $C$. clathratiforme covered $95 \%$ of the anoxygenic phototrophic community (Habicht et al. 2009). All the closest type strains assigned to our clones have been classified as freshwater species (Pfennig \& Overmann 2001). In a previous study (Taipale et al. 2009), the GSB population of Mekkojärvi was assigned to Chlorobium phaeobacteroides. The difference in the phylogenetic affiliation was due to the length of the sequences, which was longer in the present study. The 16S rRNA structures of Chlorobium species are very similar (Imhoff 2003), which makes exact differentiation to species level challenging when using short sequences.

The measured BChl concentrations and the high proportion of the characteristic LH-PCR biomarker clearly proved that GSB were abundant in more than half of the study lakes. In those lakes where GSB were present, their biomarker accounted for 13 to $42 \%$ of the PCR-amplified bacterial $16 \mathrm{~S}$ rRNA genes in the anoxic hypolimnia in July. However, the substantial increase of BChls suggested that the abundance of this group could be even higher by the end of the summer. Taipale et al. (2011) previously noted that during summer stratification, on 
average, $47 \%$ of the PCR-amplified bacterial rRNA genes in Mekkojärvi were related to the GSB, which is slightly more than in our study. According to the results of Arvola et al. (1992), hypolimnetic GSB comprised 61 to $78 \%$ of the autochthonous carbon in Mekkojärvi in summer 1986. In the GSB-positive lakes, BChl made up roughly 52 to $98 \%$ of the total amount of chlorophyll (Fig. S3). Although the actual concentrations of $\mathrm{chl} a$ and $\mathrm{BChl}$ do not provide the whole picture for the number or biomass of GSB relative to phytoplankton, they can give some estimate of the relative photosynthetic potential of the GSB.

In conclusion, the results corroborate that the occurrence of GSB in small boreal lakes is widespread in spite of the poor PAR conditions. More attention should be paid to the actual photosynthetic activity and primary production rates of Chlorobium sp. cells before their ecological significance in the energy mobilization of boreal lakes can be determined.

Acknowledgements. We thank the Lammi Biological Station for providing us with good facilities and chemistry results, as well as Miika Sarpakunnas for helping in the field. The study was supported by the Academy of Finland (Project 140706), Lammi Biological Station, and the Societas Biologica Fennica Vanamo and Olvi foundations. Finally, we thank Dr. Shawn Devlin for nice comments and for checking the English language.

\section{LITERATURE CITED}

Amann RI, Stromley J, Devereux R, Key R, Stahl DA (1992) Molecular and microscopic identification of sulfatereducing bacteria in multispecies biofilms. Appl Environ Microbiol 58:614-623

> Arvola L, Salonen K, Kankaala P, Lehtovaara A (1992) Vertical distributions of bacteria and algae in a steeply stratified humic lake under high grazing pressure from Daphnia longispina. Hydrobiologia 229:253-269

Baker A, Kromer-Baker K, Tyler PA (1985) Fine-layer depth relationships of lakewater chemistry, planktonic algae and photosynthetic bacteria in meromictic lake Fidler, Tasmania. Freshw Biol 15:735-747

Burke CM, Burton HR (1988) The ecology of photosynthetic bacteria in Burton Lake, Vestfold Hills, Antarctica. Hydrobiologia 165:1-11

> Frigaard NU, Larsen KL, Cox RP (1996) Spectrogromatography of photosynthetic pigments as a fingerprinting technique for microbial phototrophs. FEMS Microbiol Ecol 20:69-77

Gich FB, Borrego CM, Martinez-Planells A, Steensgaard DB, Garcia-Gil J, Holzwarth A (2001) Variability of the photosynthetic antenna of Pelodictyon clathratiforme population from a freshwater holomictic pond. FEMS

Editorial responsibility: Rutger de Wit, Montpellier, France
Microbiol Ecol 37:11-19

Guerrero R, Pedrós-Alió I, Mas J (1987) Communities of phototrophic sulfur bacteria in lakes of the Spanish Mediterranean region. Acta Acad Aboensis 47:125-151

Habicht KS, Miller M, Nielsen LF, Frigaard NU, Andersen JS (2009) Proteomic study of Chlorobium clathratiforme in Lago di Cadagno, Switzerland. Goldschmit Conference Abstracts 2009, A484, available at http://gold schmidtabstracts.info/2009/484.pdf

Imhoff JF (2003) Phylogenetic taxonomy of the family Chlorobiaceae on the basis of 16S rRNA and fmo (FennaMatthews-Olson protein) gene sequences. Int J Syst Evol Microbiol 53:941-951

Lane DJ (1991) 16S/23S rRNA sequencing. In: Stackebrandt E, Goodfellow M (eds) Nucleic acid techniques in bacterial systematic. John Wiley \& Sons, New York, NY, p 115-175

Muyzer G, Dewaal EC, Uitterlinden AG (1993) Profiling of complex microbial populations by denaturing gradient gel electrophoresis analysis of polymerase chain reaction-amplified genes coding for $16 \mathrm{~S}$ ribosomal-RNA. Appl Environ Microbiol 59:695-700

> Olson JM (1998) Chlorophyll organization and function in green photosynthetic bacteria. Photochem Photobiol 67: 61-75

Peura S, Eiler A, Bertilsson S, Nykänen H, Tiirola M, Jones RI (2012) Distinct and diverse anaerobic bacterial communities in boreal lakes dominated by candidate division OD1. ISME J 6:1640-1652

Pfennig N, Overmann J (2001) Genus I. Chlorobium. In: Boone DR, Castenholz RW, Garrity GM (eds) Bergey's manual of systematic bacteriology, Vol 1, 2nd edn. Springer, New York, NY, p 605-610

Salonen K, Arvola L, Rask M (1984) Autumnal and vernal circulation of small forest lakes in southern Finland. Verh Int Verein Limnol 22:103-107

> Suzuki M, Rappé MS, Giovannoni SJ (1998) Kinetic bias in estimates of coastal picoplankton community structure obtained by measurements of small-subunit rRNA gene PCR amplicon length heterogeneity. Appl Environ Microbiol 64:4522-4529

Taipale S, Jones RI, Tiirola M (2009) Vertical diversity of bacteria in an oxygen-stratified humic lake, evaluated using DNA and phospholipid analyses. Aquat Microb Ecol 55:1-16

Taipale S, Kankaala P, Hahn MW, Jones RI, Tiirola M (2011) Methane oxidizing and photoautotrophic bacteria are significant producers in an oxygen-stratified humic lake. Aquat Microb Ecol 64:81-95

Van Gemerden H, Mas J (1995) Ecology of phototrophic sulfur bacteria. In: Blankenship RE, Madigan MT, Bauer CE (eds) Anoxygenic photosynthetic bacteria. Kluwer Academic Publishers, Dordrecht, p 49-85

Vila X, Abella CA, Figueras JB, Hurley JP (1998) Vertical models of phototrophic bacterial distribution in the metalimnetic microbial communities of several freshwater North American kettle lakes. FEMS Microbiol Ecol 25: 287-299

Wetzel RG (ed) (1983) Limnology, 2nd edn. Saunders Coll., Philadelphia, PA

Submitted: May 3, 2012; Accepted: January 30, 2013

Proofs received from author(s): March 8, 2013 